\title{
The Trial of Thomas Hardy
}

\section{A Forgotten Chapter in the Working-Class Fight for Democratic Rights}

\section{AN ANGUS}

November 5, 2019, is the 225th anniversary of the acquittal of Thomas Hardy on charges of High Treason. Hardy is nearly forgotten today, but for decades workers and democrats in England celebrated November 5 as the anniversary of a major victory, a triumph over a powerful state that had deployed immense resources to crush working-class organizations and suppress popular demands for democratic rights.

Hardy was born in Scotland on March 3, 1752, the son of a sailor who died at sea when Thomas was eight. He moved to London in 1774, where he worked as a shoemaker, a trade he had learned from his grandfather.

Only a tiny minority of working people in the 1790s worked in anything we would recognize as a factory. As Marxist historian E. P. Thompson writes, "the characteristic industrial worker worked not in a mill or factory but (as an artisan or 'mechanic') in a small workshop or in his own home."

Hardy was one of these artisans. After working for others for seventeen years, he opened his own small shop in Piccadilly in 1791. As he later wrote, the experience of trying to set up a shop during economically hard times forced him to think. The country was rich and the people worked hard - so why was it so difficult to make ends meet?

It required no extraordinary penetration, once the enquiry was begun, to be able to trace it to the corrupt practices of men falsely calling themselves the representatives of the people, but who were, in fact, selected by a comparatively few influential individuals, who preferred their own particular aggrandizement to the general interest of the community.

The next enquiry naturally arose - Was the cause of the people hopeless? Must they and their posterity for ever groan under this intolerable load? Could not the nation, by a proper use of its moral powers, set itself free? ${ }^{2}$

England in the eighteenth century was not, by any stretch of the imagination, a democracy. Large landowners were firmly in charge and the entire system was grossly corrupt. It was a government of the rich, by the rich, and for the rich.

IAN ANGUS edits the website Climate and Capitalism and is the author, most recently, of A Redder Shade of Green: Intersections of Science and Socialism (Monthly Review Press, 2017).

An earlier version of this article was published in Socialist Voice in November 2009. 
There were a few constituencies where perhaps 10 per cent of the male electorate could vote, but these were easily outnumbered by the "rotten boroughs," where the Member was effectively nominated by his patron, a lord or a landowner or both. The quarter of the population which lived in urban areas was entirely unrepresented - the franchise was still based on voting in counties and in rural areas. No more than 4 per cent of the male population was entitled to vote, and most of those either didn't vote, or voted according to how much they were bribed or patronized. ${ }^{3}$

\section{"Another Class of People"}

There had been many middle-class and even aristocratic societies for political reform in England before, but Hardy proposed something different: "A Society of another class of the people, to effect that most desirable and necessary Reform, which had baffled the united associations of men of the greatest talents, worth, and consequence in the nation." ${ }^{4}$

The result, formed on January 25, 1792, by "eight plain, homely, and obscure citizens," was the London Corresponding Society (LCS). Hardy was elected secretary and treasurer at the first meeting.

The LCS was to be an organization for and of working people. Dues were just one penny a week. Branches - limited to thirty members each in order to encourage full participation and discussion - met weekly in working-class pubs in various parts of London and the surrounding towns. When a sympathetic member of parliament joined, he was welcomed but not allowed to chair a meeting, lest the LCS be seen as allied with the Whigs. Hardy wrote: "We were so scrupulous about the admission of any of those of the higher ranks that when any of them offered to pay more than we usually demanded on the admission of a new member we would not receive it." ${ }^{5}$

The Society grew to twenty-five members in two weeks, and to two thousand in six months. Its office, in Hardy's shop, became the hub for communication and coordination among similar organizations of artisans, "mechanics," and small tradesmen throughout England, Scotland, and Wales, all devoted to campaigning for universal suffrage and annual elections. They saw those objectives not as ends in themselves, but as steps toward ending poverty and hunger.

For the rest of the decade, until it was formally outlawed by an Act of Parliament, the LCS was the largest, best-known, and (to the ruling class) most notorious working-class organization in England. At its peak in 1795, its public meetings in London were attended by one hundred thousand people and it was in communication with similar groups in over one hundred cities and towns.

Although the LCS focused on parliamentary reform, it also campaigned against the war that Britain was waging, in alliance with Europe's worst despots, to overthrow France's revolutionary government. Members of 
the LCS and other reform groups across the country were also actively involved in the nascent trade-union movement and in widespread protests against high food prices during the famine of 1794-95.

\section{Repression}

The British ruling class was outraged at the very idea that the "swinish multitude," as conservative ideologue Edmond Burke called them, might play any role in politics. In the House of Lords, a Bishop sputtered that "he did not know what the mass of the people in any country had to do with the laws but to obey them."

Such gross class prejudice was not limited to reactionaries. Christopher Wyvill, a Yorkshire landowner and prominent advocate of limited parliamentary reform, warned in 1792 that "the right of Suffrage communicated to an ignorant and ferocious Populace would lead to tumult and confusion." Referring to the popularity of Tom Paine's Rights of Man among the radicals, he wrote: "If Mr. Paine should be able to rouze up the lower classes, their interference will probably be marked by wild work, and all we now possess, whether in private property, or public liberty, will be at the mercy of a lawless and furious rabble."

Early in 1792, the government embarked on a campaign that combined antidemocratic propaganda with outright repression in order to force worker democrats off the political stage. It financed mass distribution of antiradical newspapers and pamphlets, accused the radicals of being paid agents of France, and (through Anglican Bishops, who owed their lucrative posts to the Cabinet) instructed the clergy to preach that supporters of the democratic movement would surely go to hell. At the same time, it encouraged "Church and King" mobs to attack or intimidate radical meetings, denied licenses to pub owners who rented meeting rooms to radicals, and sent spies and provocateurs into radical societies.

In June 1792, Paine was charged with seditious libel for the views expressed in Rights of Man. He escaped to France, but was tried and convicted in his absence, and Rights of Man was banned.

In Edinburgh in 1793, three men, including LCS chairman Maurice Margarot, were charged with sedition - consisting of arguing for parliamentary reform and opposing the war with France. After a trial before an openly hostile judge, they were sentenced to fourteen years of "transportation" - exile and compulsory labor in Australia.

\section{A Show Trial at Old Bailey}

On May 12, 1794, Hardy and eleven other leading figures in the reform movement were arrested. The police ransacked Hardy's home while 
his pregnant wife lay in bed. They took him first to jail and then to the Parliament buildings, where he was interrogated for several days by a committee that included the prime minister and several senior cabinet ministers. Two weeks later, Parliament passed a bill suspending habeas corpus, thus allowing the government to imprison the twelve in the Tower of London without charge for several months.

While he was in prison, a reactionary mob (Hardy believed they were paid and organized by the government) attacked Hardy's home, breaking the windows and threatening to set the building on fire. His wife escaped through a small back window, but the physical and emotional strain had fatal effects: on August 27 her baby was stillborn and she died a few hours later.

On October 6, a handpicked grand jury charged the twelve men with "High Treasons and Misprisions of Treasons, against the person and authority of the King." If convicted, each would be "hanged by the neck, cut down while still alive, disemboweled (and his entrails burned before his face) and then beheaded and quartered."

Hardy was the first in the dock, because he "was supposed to be the most helpless of this band." ${ }^{\prime}$ The government threw unprecedented resources into prosecuting him.

The trial of Thomas Hardy was the longest and most expensive trial for high treason that had ever been heard in Britain. The prosecution case was conducted by no less than eight barristers, led by the Attorney-General Sir John Scott and the Solicitor-General Sir John Mitford.... Four judges sat with [Chief Justice] Eyre on the bench....

The trial began on Tuesday 28 October 1794, and continued, with a break on Sunday, until Wednesday 5 November; no previous trial had lasted more than twenty-four hours, from the reading of the indictment to the delivery of the verdict....

Scott's opening speech, 100,000 words long, took nine hours to deliver. ${ }^{10}$

But despite all the money and time they devoted, the prosecution's case was weak. They had masses of documents and the testimony of spies and turncoats, but none of it demonstrated treason. In essence, their argument was that campaigning for political reform was equivalent to plotting to overthrow and murder the king. The prosecutors seem to have hoped that the conservative biases of a jury of property owners would prejudice them against a working-class radical who was challenging the right of property to rule.

The strategy failed. Shortly before the trial, noted political philosopher William Godwin published an essay that effectively demolished the legal basis for equating political reform with treason. It was so widely read 
and influential that one of the lawyers for the prosecution denied in court that the case depended on any such argument. Hardy's lawyer, Thomas Erskine, was devastating in his cross-examination of government witnesses and his address to the jury.

On November 5, after nine long days of trial, the jury took only three hours to decide unanimously that Hardy was not guilty.

Hardy tried to leave the building quietly, but a huge crowd of supporters surrounded his carriage, released the horses, and pulled him through the streets cheering. At his request, they took him to the cemetery, where they waited quietly while he visited his wife's grave for the first time.

Apparently believing that the Hardy verdict was a fluke, the government proceeded with treason charges against Hardy's colleagues. The trial of John Horne Tooke, a longtime moderate reformer, lasted five days; that of John Thelwall, the best-known and most popular LCS speaker, lasted three. Both were acquitted. Humiliated, the government withdrew all charges against the remaining nine radical leaders.

The show trial was part of a deliberate plan to crush the reform movement and to deny working people any role in politics. Hardy was told by a source he trusted that the government had eight hundred other warrants prepared - three hundred of them already signed - that it planned to execute as soon as it won guilty verdicts. That plan was defeated-a major setback for reaction in England.

Hardy's acquittal was a victory for the radical movement, but it was devastating for him personally. His wife had died while he was in prison; his shop and home had been destroyed; the defense had cost him every cent he had. Reading between the lines in the memoir he published years later, it seems that the experience left him emotionally drained, if not shattered. For over thirty years, Hardy was a regular participant in the annual dinners celebrating the acquittals of 1794 , but he never again played an active role in politics.

\section{The First Worker Revolutionaries}

Hardy and his comrades were not socialists. Socialist ideas did not yet exist, nor did the social forces that would make socialism possible. The radicals of the 1790s drew inspiration from the French Revolution, from the century-old traditions of the Levellers, and above all from Paine, whose Rights of Man sold an unprecedented two hundred thousand copies between 1792 and ' 93 . Socially, the radicals favored something akin to the twentieth-century welfare state. Politically, they were radical democrats. Many of their demands were not won until well into the twentieth century, and some still are not on the books. 
In their time, they were revolutionaries. As historian Roger Wells writes:

In the context of England's socio-economic and political structures in the 1790s, democratic ideology pivoting on manhood suffrage had revolutionary implications. How could a society which so ostentatiously hinged on the very unequal distribution of wealth, bolstered by a political system excluding all but the very rich, survive the implementation or imposition of democracy? $?^{11}$

After the acquittals of 1794 , it took the government several years to suppress Britain's first authentic working-class movement. It was able to do so only by passing draconian laws that greatly expanded the grounds for charges of treason, outlawed any meeting of more than fifty people, suspended habeas corpus, and finally banned all trade unions and the LCS itself in 1799.

Even then, the radicals were only driven underground. As Thompson showed in his monumental study The Making of the English Working Class, the tradition of working-class resistance to oppression remained strong. When mass protests broke out between 1815 and '19, they built on the traditions and ideas of the 1790s and were led by many of the same people.

Throughout the war years there were Thomas Hardys in every town and in many villages throughout England, with a kist or shelf full of Radical books, biding their time, putting in a word at the tavern, the chapel, the smithy, the shoemaker's shop, waiting for the movement to revive. And the movement for which they waited did not belong to gentlemen, manufacturers, or rate-payers; it was their own. ${ }^{12}$

Those radicals kept the spirit of 1794 alive in the hardest times of ruling-class repression and working-class retrenchment. In tribute to them, the victory of November 5, 1794, should be remembered today, and Hardy surely deserves to be restored to his rightful place in the pantheon of working-class heroes.

\section{Notes}

1. E. P. Thompson, The Making of the English Working Class (1963; repr., London: Penguin, 1991), 259.

2. Thomas Hardy, Memoir of Thomas Hardy, Founder of, and Secretary to, the London Corresponding Society, for Diffusing Useful Political Knowledge Among the People of Great Britain \& Ireland, and for Promoting Parliamentary Reform, from Its Establishment, in Jan. 1792, Until His Arrest, on a False Charge of High Treason, on the 12th of May, 1794: Written by Himself (London: James Ridgeway, 1832), 10.

3. Paul Foot, The Vote: How It Was Won and How It Was Undermined (London: Penguin, 2005), 46.

4. Hardy, Memoir, 103; emphasis added.

5. Mary Thale, ed., Selections from the Papers of the London Corresponding Society 1792-1799 (Cambridge: Cambridge University Press, 1983), 8.

6. R. A. Soloway, Prelates and People: Ecclesiastical Social Thought in England, 1783-1852 (London: Routledge, 1969), 63.

7. Thompson, The Making of the English Working Class, 26.
8. Thompson, The Making of the English Working Class, 21.

9. Hardy, Memoir, 110.

10. John Barrell, Imagining the King's Death: Figurative Treason, Fantasies of Regicide, 1793-1796 (0xford: Oxford University Press, 2000), 318, 324.

11. Roger Wells, Wretched Faces: Famine in Wartime England, 1793-1801 (New York: St. Martin's, 1988), 133.

12. Thompson, The Making of the English Working Class, 201. A kist was a chest, usually used for storing clothes or linen. 